\title{
The Impact of Using Reading Storybooks and Writing Journal Activities on Print and Phonemic Awareness of Jordanian Kindergarten Children
}

\author{
Ebtesam Q. Rababah* \\ Yarmouk University, Jordan
}

Received: $1 / 5 / 2016$

Accepted: 23/2/2017

\begin{abstract}
This study investigated the impact of reading storybooks and writing journal activities on print and phonemic awareness of Jordanian kindergarten children. Subjects participated in book-reading sessions with a print focus, and writing journals. A total of 50 children were recruited for the study from one kindergarten in Irbid City, Jordan. Two intact sections of 25 children each served as experimental and control groups. Pre-test measures of children's print and phonemic awareness were administered. Subsequently, children in the experimental group participated in 24 small-group reading sessions that included a print focus, and 14 writing journals over a 14-week period. As an alternate condition, control-group children participated in conventional instruction methods only. Post-testing indicated that children who participated in print-focused reading and writing journal sessions outperformed their control group peers on four measures of print awareness (words in print, print concepts, alphabet knowledge and letter discrimination, and literacy terms), and on phonemic awareness (letter sound identification, rhyme, phoneme blending, phoneme segmentation, and phonemic manipulation), as well as overall performance. Implications and future research directions are discussed.
\end{abstract}

Keywords: Writing journals, emergent literacy, print awareness, phonemic awareness, Jordan, kindergarten.

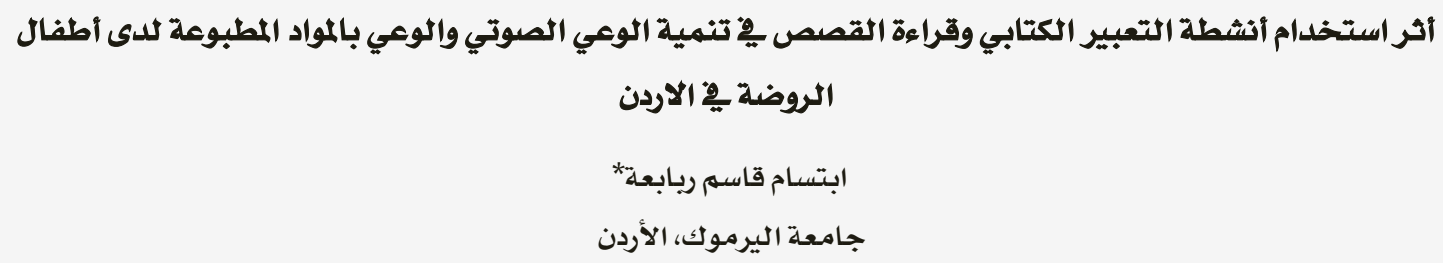


According to a national survey conducted by the Jordanian Ministry of Education in partnership with the United States Agency for International Development that included an early grade reading assessment, only $17 \%$ of Jordanian children from the second to third grade were able to read the full text and respond correctly to $80 \%$ or more comprehension questions (USAID, 2012). Undoubtedly, reading and writing are crucial elements in the education of any child. Reading skills are important to success in school and any future work as well. Ferreiro and Teberosky (1982) said, "Along with elementary arithmetic, reading and writing are the objectives of basic instruction, and their learning is condition of success or failure in school" (p. 1).

Parents and early childhood educators want children to become good readers and writers. They are fully aware of how crucial reading and writing skills are to school success (Noe, Spencer, Kruse \& Goldstein, 2014). However, according to Dickinson and Tabors (2001), parents and early childhood educators may not know how important language development is in preparing preschool-aged children for later literacy development. Dickinson and Tabors (2001) added, "More work has shown strong relationships between children's early language skills and later reading abilities" (p. 3). Furthermore, they argued, "These verbal infractions during book reading promote the development of a cluster of language skills that children will be expected to use in school" (p. 49). The authors found evidence that "both the quantity and quality of book reading that occur are associated with language performance" (p. 48).

Past research has established the critical role of phonemic awareness in the development of beginning reading (Dee Nichols, Rupley, Rickelman, \& Algozzine, 2004; Edwards, \& Taub, 2016; Manyak, 2008; Kelley, Roe, Blanchard, \& Atwill, 2015; Kilpatrick, 2012; Noe et al., 2014; Yopp \& Yopp, 2000). For example, Manyak (2008) said:

Phonemic awareness contributes centrally to children's acquisition of the alphabetic principle-the understanding that the letters of the alphabet represent phonemes in speech. This understanding makes early phonics instruction useful for children and facilitates children's ability to blend letter sounds while decoding words, to learn sight words reliably, and to spell phonetically. (p. 659)

In the last twenty years, the importance of phonological awareness in children's early reading achievement has been clearly established (Wagner \& Torgesen, 1987). In this study, phonemic awareness was used to indicate ability to analyze (e.g., segment) the individual sounds of words. Phonemic awareness refers to knowledge of the sounds of printed letters or words and how letters and words come together to make sounds (Adams, Foorman, Lundberg, \& Beeler, 1998; Edwards, \& Taub, 2016). This is helped as children begin to recognize familiar words on street signs and books at home (Armbruster, 2003).

Phonological awareness is a child's awareness of the sound structure of speech. Under phonological research, instruction should be from larger to smaller units of oral language (Cormier \& Dea 1997). Rhyme instruction and syllable segmenting help develop phonological awareness (Heroman \& Joans). Without knowledge of the separate sounds that make up words, it is difficult for children to hear separate sounds, recognize the sound's position in a word, and understand the role sounds play within the word (Ukrainetz, Cooney, Dyer, Kysar, \& Harris, 2000), and ultimately helping children learn to read (Ehri \& Nunes, 2002; Fitzpatrick, 1997; Snow, Burns, \& Griffin, 1998). It could be compared, for example, to how much more successful young chemistry students will be if they first understand the periotic table of elements, the very basic building blocks of the language of chemistry.

A considerable body of research indicates that early literacy instruction including phonemic awareness instruction, among other components such as reading literature aloud and encouraging children to write can make reading accessible at an earlier age to more children (Ehri, Nunes, Willows, Schuster, YaghoubZadeh, \& Shanahan, 2001; Snow et al., 1998). With quality instruction, research has shown that children can enter kindergarten being able to segment words into phonemes (Hesketh, 2007; Yeh, 2003).

Print awareness is a child's ability to recognize print; it also includes concepts about print, book concepts, and conventions of print. According to Justice and Vukelich (2008), careful- 
ly planned, direct instruction through environmental print activities and picture-wordletter categorization can be used to foster print awareness in preschool children. It allows opportunities for "meaningful engagements with reading and writing, and social support" in addition to direct instruction in the important skills needed to be successful in these literacy activities (Justice \& Vukelich, 2008, p. 39).

As children develop print awareness, they begin to understand the connection between oral and written language (Westwood, 2004). When developing print awareness, children learn that print carries meaning, is organized in a specific way, and that reading and writing have common rules (Heroman \& Joans, 2010). Print awareness is important because it represents a group of skills that are necessary for children to become successful readers. Children begin to develop print awareness as early as infancy and continue to develop it further throughout early childhood (Kassow, 2006).

Furthermore, Print awareness is a necessary foundational skill that children must possess in order to become proficient readers. Print awareness is developed through daily adultchild interactions with print in the child's environment and through shared reading experiences. According to Justice and Ezell (2002), reading to a child and talking about the print is the best way to increase children's print awareness. Print awareness can be increased with structured adult-child shared readings that include an explicit focus on print using both verbal and nonverbal cues (Piasta, Justice, McGinty, \& Kaderavek, 2012). Past research has shown shared reading, with prompts to focus on specific aspects of print, accelerates pre-literacy skills for children who are typically developing and those who are at risk for later reading difficulties (Justice \& Ezell, 2002; Piasta et al., 2012).

Print knowledge includes general understandings of how print works (e.g., left-to-right directionality in English; right-to-left in Arabic) and the names and sounds of the alphabet. Knowledge about sound, or phonological awareness, includes the ability to attend to and manipulate sound structures of language, progressing from awareness of larger chunks (e.g., sentences, rhyme, beginning sounds), to blending and segmenting individual units of sound (i.e., phonemic awareness). These early skills work together to lay a foundation for later reading success (NELP, 2008).

Many past researchers indicated that the most effective ways to promote early literacy development among young children is reading aloud to them (Bus, van Ijzendoorn, \& Pellegrini, 1995; IRA/NAEYC, 1998). Bingham et al (2016) examined teachers' implementation of an early literacy intervention, Systematic and Engaging Early Literacy (SEEL), on kindergarten children's development of early literacy skills. They found that learning outcomes in relation to children in the comparison group on rhyme awareness, rhyme generation, letter knowledge, and letter-sound association. Results also showed that children with limited phonological skills benefited most from the intervention.

According to Puranik, Lonigan, and Kim (2011) phonological awareness, alphabet knowledge, and concept of print are important components of the preschool children's word spelling and literacy skills. Ezell and Justice (2000) also, suggested that one salient method for enhancing children's print awareness is by structuring adult-child shared book-reading interactions to include an explicit print focus.

Justice and Ezell (2002) later evaluated the impact of participation in book-reading sessions with a print focus on print awareness in preschool children from low income households. A book-reading intervention was conducted for 30 children enrolled in Head Start. Children were matched on chronological age and then randomly placed into an experimental or control group. Pretest measures of children's print awareness were administered. Subsequently, children in both groups participated in 24 small-group reading sessions over an 8week period. Children in the experimental group participated in shared reading sessions that included a print focus. As an alternate condition, control-group children participated in shared reading sessions with a picture focus. Post-testing indicated that children who participated in print-focused reading sessions outperformed their control group peers on three measures of print awareness and in terms of overall performance.

Kamii and Manning (2002) examined the relationship between children's development in writing and their development in phonological analysis. Specifically, they investigated kindergartners' levels of writing as an inde- 
pendent variable and their performance on oral-segmentation tasks as the dependent variable. They found a highly significant multiple correlations R and concluded that: (1) children's ability to deal with oral-segmentation tasks seems to depend on their knowledge of the writing system, and (2) the ability to segment words into phonemes is not a cause or prerequisite for learning to read and write.

In conclusion, reviewing the literature showed that some research focused on phonemic awareness (Kamii \& Manning, 2002; Noe et al., 2014). Other research focused on print awareness in preschool children (Ezell \& Justice, 2000; \& Justice \& Ezell, 2000). Some research showed that reading to a child and talking about the print is the best way to increase children's print awareness. Also, print awareness can be increased with structured adultchild shared readings that include an explicit focus on print using both verbal and nonverbal cues (Piasta et al., 2012). Another suggested, "Storytelling and storybook reading provide many kinds of preparation for learning to read and write" (Clay, 2001, p. 116).

However, the limited literature on emergent literacy suggests that little is known about the print awareness and phonemic awareness in the context of the Arabic language and Jordan specifically (Ihmeideh, Al-Basheer, \& AlMomani, 2008). Therefore, the present study focused on investigating the impact of using reading storybooks and writing journal activities on print and phonemic awareness of Jordanian kindergarten children.

\section{Research Problem}

Current research suggests that many children experiencing problems learning to read during their elementary years may be related to deficiencies in their emergent literacy skills development, skills that are typically acquired during the preschool years (August \& Shanahan, 2006). August and Shanahan's (2006) research found three key emergent literacy skills that could predict children's reading ability during the elementary school years: (1) oral language proficiency, (2) phonological processing, and (3) print knowledge.

However, the purpose of this study was to investigate the impact of using reading storybooks and writing journal activities on print and phonemic awareness of Jordanian kinder- garten children. More specifically, this present study aimed to address the following questions:

1. To what extent does participation in storybook-reading sessions and writing journal activities influence the printawareness skills of kindergarten children?

2. To what extent does participation in storybook-reading sessions and writing journal activities influence the phonemicawareness skills of kindergarten children?

\section{Importance of the Study}

Based on the discussion above, it is clear that print and phonemic awareness is a necessary foundational skill that children must possess in order to become proficient readers (August \& Shanahan, 2006; Edwards, \& Taub, 2016; Ehri et al., 2001; Ehri \& Nunes, 2002; Fitzpatrick, 1997; Liberman, Shankweiler, \& Liberman, 1989; Morrow, 2009; Noe et al., 2014; Puranik et al., 2011; Snow et al., 1998; Torgesen, 1998). According to Liberman et al. (1989), the most common cause of difficulties acquiring early word-reading skills is weakness in the ability to process phonological features. Goswami (2000) mentioned, "Agreement on the importance of phoneme awareness for reading development is universal. It is probably true to say that every study that has measured the relationship between phonemic awareness causes progress in reading has found a positive connection" (p. 255).

According to Ihmeideh et al. (2008), a scarcity of empirical studies exists that tackle the development of early reading and writing for kindergarten children in Jordan. This study is the first of its kind in Jordan and strives to investigate the impact of using reading storybooks and writing journal activities on print and phonemic awareness of Jordanian kindergarten children. This study contributes valuable data and information to the literature on the field of teaching reading and writing at this age. Moreover, it also shows how much a developing country, such as Jordan, needs more support and expert people to help their children to learn reading and writing (USAID, 2012). Finally, it is hoped to pave the way for more research in this particular field. 


\section{Context of the Study}

Early childhood education in Jordan consists of two grade levels, kindergarten 1 (KG1) and kindergarten 2 (KG2) with one academic year for each level. Usually, children enter KG1 at the age of four. The aim of these two levels is to prepare children for first grade. In regard to the Arabic language, children are expected to recognize and write the 28 Arabic letters by the end of KG2. No emphasis is placed on skills beyond recognition of letters, such as formal reading and writing. The language of instruction in public kindergartens is Arabic, which is the official language in Jordan. Like English, the Arabic letters' naming system is different from the letters' sounds, which places many students in a difficult situation in learning letters. This necessitates providing students with extra help.

The Arabic language is an alphabetic language and considered a very difficult language to learn. In part, this is because the word is a connection of different letters together, which is common to many languages, but in Arabic these letters have different shapes when they connect together based on different rules. Some letters have up to four different shapes and nine different sounds when connected with other letters to make a word.

\section{Theoretical Framework}

Teaching young children how to read and write has been a long debated issue among educators. Pre-school educators do not agree on how to foster literacy awareness: some are committed to having children learn their letters to give a good preparation for entry to school, while others would leave children unaware of the existence of such things until faced with school instruction (Clay 1998). As educators increasingly are expected to implement evidence-based practice, or scientificallybased instruction (Bingham et al., 2016), in teaching children to read, more studies using various theoretical frameworks and methodologies measuring the effectiveness of various teaching methods are badly needed. When these studies show repeated positive results for learning, curriculum should move toward these types of instruction (Noe et al., 2014).

This study followed the same theoretical framework established by Marie Clay, a researcher from New Zealand (1967). In 1966 Clay defined emergent literacy as early read- ing and writing behaviors young children show that are not yet conventional (Muzevich, 1999). The field of emergent literacy research has grown since Clay first defined it. Emergent literacy calls for abundant writing in the kindergarten classrooms, with the children's emergent writing forms and functions being accepted and encouraged. Barone and Hong $\mathrm{Xu}$ (2007) (p. 110), indicated that "learning to write is not just about learning the alphabet and sound-symbol relationship and putting them on paper; it is cognitive change for the child." Language acquisition is a constructive process. The child constructs increasingly sophisticated language structures and sociolinguistic knowledge without being taught by adults in a formal way. Children construct oral language by transacting with others in a language-rich environment. Likewise, written language is a constructive process.

The construction of written language continues to develop when formal instruction begins with the advent of schooling. Indeed, the acquisition of literacy proceeds similarly (but not identically) to the acquisition of oral language in situations where children receive encouragement, support, and response. They are expected to progress and succeed with both oral and written language.

This study also followed Vygotsky's theory of language development (1978), which states that the children's home, school, and community environments influence early literacy development. Reading involves a transaction between a reader and a text. Reading and writing are complex cognitive, physical, and social processes. The reader-text transaction occurs within a social and situational context. These social and situational contexts influence how a child develops in early literacy.

\section{Research Hypotheses}

Based on the existing literature, the gaps in it, and the objectives of this study, the following hypotheses were identified to examine the impact of using reading storybooks and writing journal activities on print and phonemic awareness of Jordanian kindergarten children:

- Hypothesis 1: storybook-reading sessions that include a print focus and writing journal activities will have a significant impact on the printawareness skills of the kindergarten children tested. 
- Hypothesis 2: storybook-reading sessions that include a print focus and writing journal activities will have a significant impact on the phonemicawareness skills of the kindergarten children tested.

Thus, the independent variables for this study were reading storybooks and writing journal activities which utilized in the experimental group, and the conventional way in the control group. While, the dependent variable were the student's print and phonemic awareness

\section{Method}

\section{Study Design}

This study used a quasi-experimental research design in which children were randomly assigned either to an experimental or control classroom. Program staff randomly assigned the children upon their enrolment in this public school. The typical protocol at this public school setting was that students were randomly assigned to one of two kindergarten classrooms upon admission into the program. The study was conducted over 14 weeks, with the first and last week devoted to pre and post testing. The intervening 12 -week period was used to deliver the experimental language stimulation activities twice weekly.

\section{Participants}

Fifty KG2 children (23 boys, and 27 girls; mean age before intervention $=62.19$ months; $\mathrm{SD}=$ 2.27) were recruited from one school in second Irbid district's public school of Jordan, which previously agreed to be part of the study. Parents of all 50 children gave permission for their children to take part in the study. All children belonged to the middle socioeconomic class according to the living standards of Jordan. The children were in two sections; one section was randomly assigned to the experimental group (EG) and the other to the control group (CG). The EG had 12 boys and 13 girls, while the CG had 11 boys and 14 girls.

The principal of the kindergarten, as well as their supervisor, judged the teachers in both groups as functionally equivalent. Both teachers have bachelor's degrees in early childhood education from the same university; the experimental teacher has 7 years of experience and the control teacher has 8 years of experience.
Both teachers had an overall evaluation by the educational district as excellent for the last three years.

\section{Data Collection}

This study aimed at enhancing children's print and phonemic awareness skills. Children in the experimental group participated in 24 small-group reading sessions and in 14 writing journals over a 14-week period to enhance their print and phonemic awareness skills. Children' parents received a letter describing the goals and methods of the study. They were asked to voluntarily allow their children to participate in this study, and a signed informed consent was also obtained from parents by the researchers after gaining the permission from school, and teachers. To ensure anonymity of participants and confidentiality of data, parents were assured that their children's responses would be used for research purposes only.

Data were collected through individual interviews with children. Through the interview, children were tested on nine different skills. Print awareness and phonemic awareness assessments were subjected to pilot testing using a 15 children out of the research sample was first made in order to assess the study's reliability. From the pilot, the test and retest reliability for the print awareness assessment was 0.87 and for the phonemic awareness assessment was0.82. Also, The Cronbach Alpha method was used to test the reliability for calculating the internal consistency for each assessment. The internal consistency of the print awareness assessment was between 0.87-0.71, and the internal consistency of the phonemic awareness assessment was between 0.92-0.85. This result means that the reliability coefficient was satisfactory for the purpose of this study.

Furthermore, eight experts in the Arabic language and early childhood education judged the tests; they helped to translate and adapt the instruments (pre, and post test) into the Arabic language to maintain their validity. Details for each skill follow below.

Print awareness assessment. Four informal measures for examining children's early literacy skills were administered during pretest and posttest. The measures were administered in the same order to each child to avoid possible negative order effects that might have oc- 
curred if similar tasks were presented consecutively or if more difficult tasks were presented before easier tasks; since the measures were applied individually (2007; Soman, 2014 ). Table 1 provides an overview of the assessment protocol.

Table 1

Print Awareness Assessment

\begin{tabular}{|c|c|}
\hline Measure & Focus \\
\hline Print Concepts & $\begin{array}{l}\text { Print- and book-reading } \\
\text { conventions }\end{array}$ \\
\hline Words in Print & $\begin{array}{l}\text { Words as elements of } \\
\text { written language }\end{array}$ \\
\hline $\begin{array}{l}\text { Alphabet Knowledge and } \\
\text { Letter Discrimination }\end{array}$ & $\begin{array}{l}\text { Letter names (expressive } \\
\text { and receptive) and dis- } \\
\text { tinctive features of let- } \\
\text { ters }\end{array}$ \\
\hline Literacy Terms & Written language terms \\
\hline
\end{tabular}

Print concepts. This test represented a modification of Clay's (1979) Concepts About Print test. Adaptation occurred primarily to make the test more appropriate for the Arabic language. The purpose of the modified test was to determine children's knowledge of print and book-reading conventions in the Arabic language. Following Clay's protocol, the examiner read the target book with the child, during which the child was presented a series of tasks (e.g., "Show me the front of the book," and "Show me the name of this book"). Correct responses typically received 1 point. The total number of possible points was 20 .

For Words in Print, Alphabet knowledge and letter discrimination, and Literacy terms assessment protocol (Clay, 1967; 1979; Ihmeideh, 2009; Justice \& Ezell, 2002; Morrow, 2004), which was designed and adapted to the Arabic language and to display the selection of the follow print awareness skills.

Words in print. This measure examined children's awareness of printed words as discrete elements of written language. For example, displaying the cover of the book, the examiner said to the child: "How many words are in the name of this book?" Examples of additional tasks included "Show me the first word on this page," and "Point to the words as I read." Children received 2 points for correct responses and 0 points for incorrect responses. The total number of points available was 20 .

Alphabet knowledge and letter discrimination. To determine children's knowledge of the alphabet, 20 tasks (10 receptive and 10 expressive) were presented using alphabet cards that depicted the letters of the alphabet. For the expressive tasks, children were asked to choose a card from an array, one at a time, and to name each letter as it was chosen. To test receptive knowledge of the alphabet, children were asked to point to each letter as the examiner named it. Furthermore, for all 20 tasks, children were shown the target letter and were asked to point to an item from the array that was the same. One point was given for correct items, for a total of 20 possible points.

Literacy terms. This subtest examined children's understanding of written language units and print terms. A set of 20 cards was developed and used for this purpose. Each card depicted four written language concepts among the targeted written language units including: reading, writing, print, number, letter, letter's shape, question mark, word, and sentence. Each unit was tested twice using different foils. Incorrect responses were scored as 0, whereas correct responses received one point each. The maximum score was 20.

Phonemic awareness assessment. Phonemic awareness is the ability to hear the separate sounds that comprise spoken words. It involves perceiving the relationships between sounds and having the ability to alter and rearrange sounds to create new words. Table 2 provides an overview of the Phonemic assessment protocol (Peter, 2007; The National Reading Panel, 2000; Yopp \& Yopp, 2000, Ukrainetz et al., 2000), which was designed and adapted to the Arabic language and to display the selection of phonemic awareness skills.

Table 2

Phonemic Awareness Assessment

\begin{tabular}{|c|c|}
\hline Tool & What Is Assessed \\
\hline $\begin{array}{l}\text { First Sound Identi- } \\
\text { fication }\end{array}$ & $\begin{array}{l}\text { A child's ability to identify the } \\
\text { first letter sounds, }\end{array}$ \\
\hline $\begin{array}{l}\text { Last Sound Identi- } \\
\text { fication }\end{array}$ & $\begin{array}{l}\text { A child's ability to identify the } \\
\text { first letter sounds, }\end{array}$ \\
\hline Rhyme Supply & $\begin{array}{l}\text { A child's ability to generate a } \\
\text { word that rhymes with an audito- } \\
\text { ry prompt. }\end{array}$ \\
\hline Phoneme Blending & $\begin{array}{l}\text { Awareness of individual pho- } \\
\text { nemes and awareness of ways to } \\
\text { create word patterns with pho- } \\
\text { nemes. (Listening to a sequence of } \\
\text { separately spoken sounds and } \\
\text { combining them to form a recog- } \\
\text { nizable word). }\end{array}$ \\
\hline $\begin{array}{l}\text { Phoneme Segmen- } \\
\text { tation }\end{array}$ & $\begin{array}{l}\text { Awareness of individual pho- } \\
\text { nemes and the auditory position } \\
\text { of phonemes in a word. Also } \\
\text { breaking a word into its sounds } \\
\text { by counting the sounds in each } \\
\text { word }\end{array}$ \\
\hline
\end{tabular}




\section{Procedures}

In order to have suitable and safe results that were statistically testable, a practical pretest for the achievement of both groups was conducted; means and standard deviations were computed with t-tests as well. The results showed no significant differences $(p=.05)$ between group means for the pre-test, reflecting the sample homogeneity and sufficiency.

The control group was taught in the conventional way followed by the kindergarten. In the conventional way, many teachers in Jordan focus with start showing the letter and then giving three to four words which include the letter that the teacher thought without focus on the letter's sound in each word. Then the teacher gives the children the time to write the letter, with no opportunities to read and write about the experience; there is no practice on free writing or reading stories. The experimental group, however, was taught through a program that involved children in 24 smallgroup reading sessions and in 14 writing journal sessions over a 14-week period to enhance their print and phonemic awareness skills. Both groups followed the same curriculum and covered the same content.

The experimental teacher was familiarized with the program through six 1-hour individual training sessions conducted by the author. Each consecutive session was separated by 3 to 5 days. After each session, the teacher reviewed what was learned at home and brought questions to the trainer in the next session. Further, this teacher was observed by the trainer during the implementation of the intervention and given feedback on her performance. In the first month of class, the teacher was observed twice a week. After that, she was observed once a week for 3 months.

In classroom sessions, children in the experimental group received oral language stimulation and exposure to emergent literacy concepts. The goal was to increase the children's language and literacy proficiency. Storybookreading that features the targeted letter was presented to the children. In this manner the children were introduced to a letter and its sound within the context of intact, whole language. Reading aloud supports the teaching of a child's concept of story, development of literary appreciation, the sharpening of awareness of the elements of design, and introduc- ing literary elements. The task of the emergent literacy teacher is to sell children on the joy and pleasure of reading.

Furthermore, on each Thursday of the instruction, classroom teachers led circle time and asked children to draw, write, and show their journals around the circle and respond to teacher questions about the events depicted. On Thursdays, during choice time, the teacher applied Piagetian principles of re-presentation of verbal and nonverbal concepts (Piaget, 1959) in a new context. This was accomplished by working individually with each child to redraw the main components from the original journal entry on a larger piece of plain paper while talking with the child about the events, adding details, and encouraging new vocabulary.

The first phase of interviews was conducted in the first week of the second semester (Spring 2015), while the second phase occurred in the last week of the same semester. The researcher conducted all interviews. The interview took place in a quiet room in the kindergarten. The interviewer started by giving the child a little gift and talking to him or her for about two minutes as an ice breaker. Then, the author started to ask children to perform the tasks. Tasks were presented in the same order for all children. Materials relevant to each task were made available for the child and then replaced by others depending on the type of the task.

\section{Data Analysis}

To assess the print and phonemic awareness, children's raw scores from both pretest and posttest were entered for analysis using SPSS, with significance alpha levels set at $p=.05$. Specifically, means, standard deviations, and Multivariate analysis of variance (MANOVA) were computed. (MANOVA) is considered an appropriate procedure when multiple dependent measures are collected over time (pretest and post-test), therefore was appropriate for testing significance here (Stevens, 1996). "Group" served as the between-subjects variable, whereas "time" served as the withinsubjects variable.

\section{Results}

To answer the first research question concerning the extent participation in storybookreading sessions and writing journal activities influences the print-awareness skills of 
Table 3

Pre and Post Test Performance of Print Awareness Composite by Group over the Time

\begin{tabular}{|c|c|c|c|c|c|c|c|c|}
\hline \multirow{3}{*}{\begin{tabular}{l}
\multicolumn{1}{c}{ Measure } \\
Print \\
Awareness \\
Composite
\end{tabular}} & Group & & & & & $\mathrm{df}$ & F value & Pvalue \\
\hline & & $\mathrm{M}$ & SD & $\mathrm{M}$ & $\mathrm{SD}$ & \multirow[b]{2}{*}{46} & \multirow[b]{2}{*}{9.962} & \multirow[b]{2}{*}{.006} \\
\hline & $\begin{array}{l}\text { Experimental } \\
\text { Control }\end{array}$ & $\begin{array}{r}50.163 \\
49.2\end{array}$ & $\begin{array}{l}18.55 \\
13.11\end{array}$ & $\begin{array}{r}64.100 \\
54.1\end{array}$ & $\begin{array}{r}20.79 \\
17.8\end{array}$ & & & \\
\hline
\end{tabular}

Table 4

Pre and Post Test Performance of phonemic Awareness by Group

\begin{tabular}{lcccccccc}
\multicolumn{1}{c}{ Measure } & Group & \multicolumn{2}{c}{ Pretest } & \multicolumn{2}{c}{ Posttest } & dF & F value & P value \\
\hline $\begin{array}{l}\text { Phonemic } \\
\text { Awareness }\end{array}$ & Experimental & M & SD & M & SD & & & \\
Composite & & 40.5 & 13.1 & 59.0 & 17.8 & 45 & 5.231 & $.035^{*}$ \\
& & & & & & & & \\
& Control & 39.1 & 11.1 & 47.0 & 13.1 & & & \\
\hline
\end{tabular}

kindergarten children, and to test the first hypothesis which stated the storybook-reading sessions that include a print focus and writing journal activities will have a significant impact on the print-awareness skills of the kindergarten children tested, means and standard deviations for the pre and post student-learning scores were used to determine the common aspects. A visual comparison of the two groups' performance from pre to post test on the print awareness is presented in Table 3.

Visual inspection indicates that the mean scores for children in both groups increased from pre- to posttest across all measures. Data also suggests that the gains made by the experimental group $(M=64.1)$ were greater than those of the control group $(M=54.1)$ on all measures. Statistical analyses were conducted to determine if gains made by children in the experimental condition were significantly different from those that occurred for children in the control condition. Furthermore, results of the MANOVA showed a significant main effect for group in print awareness $(\mathrm{F}(4,46)=$ $9.962, p=.006$, in favor of the experimental group; which means that the experimental group demonstrated a greater increase in print awareness performance over time compared to the control group.

To answer the second research question concerning the extent participation in storybookreading sessions and writing journal activities influences the phonemic-awareness skills of kindergarten children, and to test the first hypothesis which stated storybook-reading sessions that include a print focus and writing journal activities will have a significant impact on the phonemic-awareness skills of the kindergarten children tested. The means and standard deviations for the pre and post student-learning scores were used to determine the common aspects which presented in Tale 4.

The data presented in Table 4 shows the mean score of the experimental group was 40.5 with a standard deviation of 13.1 on the phonemic awareness' pre-test, while the mean score of the post-test on the phonemic awareness' was 64.0 with a standard deviation of 17.8. Data also suggests that the gains made by the experimental group were greater than those of the control group on all measures as well.

Furthermore, results of the MANOVA showed a significant main effect for group in phonemic awareness $\left.\mathrm{F}_{(5,45)}=5.231, p=.035\right)$, in favor of the experimental group; which means that the experimental group demonstrated a greater increase in phonemic awareness performance over time compared to the control group.

\section{Discussion}

Results from this study revealed a significant positive influence from reading storybooks and writing journal activity sessions in the Arabic-language kindergarten students tested. The present results support the findings of Justice and Ezell (2000), in which children who participated in shared home reading sessions with a print focus demonstrated greater gains in pre-literacy skills compared to children in a control group. The present study extends these researchers' earlier work by investigating both reading storybooks and writing journal activities and its impact on print and phonemic awareness of Arabic-language Jordanian kindergarten children within a public school setting.

Analysis of pretest-posttest scores for print and phonemic awareness showed that children in both groups demonstrated significant gains in print and phonemic awareness from 
pre to post test. However, the children in the experimental group made significantly greater gains than those in the control group. This result is supported by previous studies (Bus et al., 1995; Clay, 2001; Edwards \& Taub, 2016; Ezell \& Justice, 2000; Justice \& Ezell, 2000; Noe et al., 2014). The next question that arises here is why did the book reading and journal writing affect children's print awareness and phonemic awareness so strongly? One possibility is that children from the ages of 3 to 5 rapidly develop print awareness when adults engage in activities to build their early literacy skills (Bingham et al., 2016; Ihmeideh, 2013). Without print awareness, children will not develop letter sound correspondence, word reading skills, or the ability to read and understand text (Ihmeideh, 2013). It is also having daily writing activities in which they can develop general concepts about writing and learn to attend to finer features of writing (Morrow \& McGee, 2005; NELP, 2008), and share their writing (Walmsley \& Walmsley, 1996).

Another possibility is that children in the experimental group were prompted by the adult reader to attend to words as elements of written language. Children in the control group, by contrast, did not receive this type of explicit guidance (Puranik et al., 2011).

Additionally, these children's ability to deal with oral-segmentation tasks seemed to depend on their knowledge of the writing system, which was developed through writing journal sessions. These specific findings support the previous research of Edwards and Taub (2016) and Kamii and Manning (2002). Edwards and Taub (2016) found Statistically significant relationships between blending and segmenting skills and blending and reading comprehension. Furthermore, according to Ukrainetz (2000), “Children can learn phonemic awareness in a naturalistic approach consistent with the principles of emergent literacy instruction. Sounds in words can be discussed within conversations embedded in storybook reading and story writing" (p. 531). However, Kilpatrick (2012) considered phoneme segmentation skills as the sole measure of phonemic awareness on reading instruments.

In summary, the present research found that participation in reading sessions and writing journals enhanced children's performance in several specific areas of print and phonemic awareness and in terms of overall performance.

\section{Conclusion}

The aim of this research was to examine the impact of using reading storybooks and writing journal activities on print and phonemic awareness of Jordanian kindergarten children. This study found a positive impact of reading storybooks and writing journal activities on print and phonemic awareness of Arabiclanguage Jordanian kindergarten children. This gives evidence to the importance of reading storybooks to kindergarten-aged children and having them do writing journal activities to increase emergent literacy. It also furthers the evidence-based support for using these types of activities in the classroom. Thus, in order for reading and writing to continue emerging and developing in kindergarten children, they need to be deeply involved in a print-rich environment and need to have ample opportunities to explore language as language-users in the same way they learn to speak (Ihmeideh, 2013; Justice, 2007; Miller, 2000).

Many interesting implications arise from these findings as well. First, every early childhood classroom and home-study setting within home schooling environments should have a reading and writing area where books and writing materials are plentiful. In the early childhood classroom, this area should be friendly and relaxing, affording young readers the opportunity for individual and small group socializing. Moreover, in language-rich environments, the child's decoding phonic skills grow fast and they should be encouraged to sound out words and try their skills at writing.

This study only focused on Jordanian kindergarteners in one public school setting, future studies could examine differences between public compared to private schools, or between different language learners at the same age, or even compare if there are regional differences among Arabic-speaking countries compared to Jordan. Also further studies could investigate the effect of play and specific activities on print and phonological awareness. All of these variations would help to further generalize the benefits of these activities for this age population. 
Finally, children come to preschool with different knowledge bases about language and literacy. Teachers can further this awareness with high-quality literacy experiences that are developmentally appropriate, "Differentiated instruction is a pedagogical approach to teaching that acknowledges and responds to student differences in readiness, interests, and learner profiles" (Justice \& Vukelich, 2008, p. 224). These activities are ideal for teaching early literacy skills to preschoolers because it allows the teacher to meet the children at their needs, all while allowing children to work at their own comfort level (Copple \& Bredekamp, 2009).

\section{References}

Adams, M. J., Foorman, B. R., Lundberg, I., \& Beeler, T. (1998). Phonemic awareness in young children: A classroom curriculum. Baltimore, MD: Brookes.

Armbruster, B. B. (2003). A child becomes a reader: Kindergarten to grade 3. Washington, DC: National Institute for literacy.

August, D., Shanahan, T. (2006). Developing literacy in second language learners: Report of the National Literacy Panel on minoritylanguage children and youth. Mahwah, NJ: Lawrence Erlbaum.

Bingham, G. E., Culatta, B., \& Hall-Kenyon, K. M. (2016). Examining the impacts of systematic and engaging early literacy (SEEL): Attention to teacher practices and classroom effects across the kindergarten year, Journal of Research in Childhood Education, 30(4), 494-512, DOI: 10.1080/02568543.2016.1216021.

Bus, A. G., van Ijzendoorn, M. H., \& Pellegrini, A. D. (1995). Joint book reading makes for success in learning to read: A metaanalysis on intergenerational transmission of literacy. Review of Educational Research, 65(1), 1-21.

Clay, M. (1967). The reading behaviour of fiveyears-old children: A research report. New Zealand Journal of Educational Studies, 2, 11-31.

Clay, M. (1998). By different paths to common outcomes. York, MN: Stenhouse Publishers.
Clay, M. M. (2001). Change over time in children's literacy development. Portsmouth, NH: Heinemann.

Copple, C., \& Bredekamp, S. (2009). Developmentally appropriate practice in early childhood programs ( $3^{\text {rd }}$. Ed). Washington, DC: National Association for the Education of Young Children.

Cormier, P. \& Dea, S. (1997). Distinctive patterns of relationship of phonological awareness and working memory with reading development. Reading and Writing 9, 207-240.

Dee Nichols, W., Rupley, W. H., Rickelman, R. J., \& Algozzine, B. (2004). Examining phonemic awareness and concepts of print patterns of kindergarten students. Reading Research and Instruction, 43(3), 5682. DOI:10.1080/19388070509558411

Dickinson, D. K. \& Tabors, P. O. (2001). (Eds.). Beginning literacy with language. Baltimore, MD: Paul H. Brookes.

Edwards, O. W., \& Taub, G. E. (2016) The influence of specific phonemic awareness processes on the reading comprehension of African American students, Journal of Research in Childhood Education, 30(1), 7484, DOI: 10.1080/02568543.2015.1105332

Ehri, L. C., \& Nunes, S. R. (2002). The role of phonemic awareness in learning to read. In A. E. Farstrup \& S. J. Samuels (Eds.), What research has to say about reading instruction (3rd Ed.) (pp. 110-139). Newark, Delaware; International Reading Association.

Ehri, L. C., Nunes, S. R., Willows, D. M., Schuster, B. V., Yaghoub- Zadeh, Z., \& Shanahan, T. (2001). Phonemic awareness instruction helps children learn to read: Evidence from the National Reading Panel's meta-analysis. Reading Research Quarterly, 36(3), 250-287. doi:10.1598/RRQ.36.3.2

Ezell, H. K., \& Justice, L. M. (2000). Increasing the print focus of adult-child shared book reading through observational learning. American Journal of Speech-Language Pathology, 9, 36-47.

Ferreiro, E., \& Teberosky, A. (1982). Literacy before schooling. Portsmouth, NH: Heinemann. 
Fitzpatrick, J. (1997). Phonemic awareness: Playing with sounds to strengthen beginning reading skills. Cypress, CA: Creative Teaching Press

Goswami, U. (2000), "Phonological and Lexical Processes." In Barr R, Kamil M, Mosenthal P., and Pearson D. (2000) Handbook of Reading Research Vol 3: 241-268.

Haroman, C., \& Jones, C. (2010). Literacy: The creative curriculum approach. Washington DC: Teaching Strategies.

Hesketh, A. (2007). Teaching phoneme awareness to pre-literate children with speech disorder: A randomized controlled trial. International Journal of Language \& Communication Disorders, 42(3), 251-271. doi:10.1080/13682820600940141.

http://www.talaris.org/wpcontent/uplo ads/EnviroPrintAwareness1.pdf

Ihmeideh, F. (2009). The effect of print-rich classroom environment on developing kindergarten children's awareness of written language, Jordan Journal of Educational Sciences, 5(1), 59-69.

Ihmeideh, F. (2013). Literacy development in early childhood. Amman, Jordan: Dar Alfiker.

Ihmeideh, F., Al-Basheer, A., Al-Momani, I. (2008). Jordanian student teachers' perceptions of teaching writing in kindergartens during their field training experience. European Journal of Teacher Education, 31(4), 403-417.

Justice, L. M., \& Ezell, H. K. (2000). Stimulating children's emergent literacy skills through home-based parent intervention. American Journal of Speech-Language Pathology, 9, 257-268.

Justice, L. M., \& Ezell, H. K. (2002). Use of storybook reading to increase print awareness in at risk children. American Journal of Speech-Language Pathology, 11(1), 17-29.

Justice, L. M., \& Vulelich, C. (Eds). (2008). Achieving excellence in preschool literacy instruction. New York: The Guilford Press.

Kamii, C., \& Manning, M. (2002). Phonemic awareness and beginning reading and writing. Journal of Research in Childhood Education, 17(1), 38-46.
Kassow, D. (2006). Environmental print awareness in young children, Talaris Research Institute, 1(3), 1-8. From::

Kelley, M. F., Roe, M., Blanchard, J., \& Atwill, K. (2015). The influence of Spanish vocabulary and phonemic awareness on beginning English reading development: A Three-Year (K-2nd) Longitudinal Study, Journal of Research in Childhood Education, 29(1), 42-59, DOI: 10.1080/02568543.2014.973127

Kilpatrick, D. A. (2012). Phonological segmentation assessment is not enough: A comparison of three phonological awareness tests with first and second graders. Canadian Journal of School Psychology, 27(2), 150-165. doi:10.1177/0829573512438635.

Liberman, I. Y., Shankweiler, D., \& Liberman, A. M. (1989). The alphabetic principle and learning to read. In D. Shankweiler \& I. Y. Liberman (Eds.), Phonology and Reading Disability: Solving the Reading Puzzle. Research Monograph Series. Ann Arbor: University of Michigan Press.

Manyak, P. C. (2008), Phonemes in use: Multiple activities for a critical process. The Reading Teacher, 61: 659-662. doi: 10.1598/RT.61.8.8.

Morrow, L. (2004). Literacy development in the early years: helping children read and write. (5th Ed). Boston: Allyn and Bacon.

Morrow, L. M. (2009). Literacy development in the early years: Helping children read and write. Boston: Allyn and Bacon.

Morrow, L., \& McGee, L. (2005). Teaching literacy in kindergarten. London: Guilford Press.

National Early Literacy Panel. (2008). Developing early literacy: Report of the National Early Literacy Panel. Washington, DC: National Institute for Literacy. From: http://www.nifl.gov/earlychildhood/N ELP/ NELPreport.html

National Reading Panel. (2000). Teaching children to read: An evidence-based assessment of the scientific research literature on reading and its implications for reading instruction (NIH Publication No. 00-4769). Washington, DC: U.S. Government Printing Office. 
Noe, S., Spencer,T. D., Kruse, L., \& Goldstein, H. (2014). Effects of a Tier 3 Phonological Awareness Intervention on Preschoolers' Emergent Literacy, Topics in Early Childhood Special Education, 34(1) 27-39.

Peter, F. (2007). Phonological awareness and the use of phonological similarity in letter-sound learning. Journal of Experimental Child Psychology, 98(3), 131-152.

Piaget, J. (1959). The language and thought of the child. 3rd ed. London: Routledge \& Kegan Paul. (Original work published 1926.)

Piasta, S. B., Justice, L. M., McGinty, A. S., \& Kaderavek, J. N. (2012). Increasing young children's contact with print during shared reading: Longitudinal effects on literacy achievement. Child Development, 83(3), 810-820.

Puranik, C. S., Lonigan, C. J., \& Kim, Y. (2011). Contributions of emergent literacy skills to name writing, letter writing, and spelling in preschool children. Early Childhood Research Quarterly 26(4): 465474.

Snow, C. E., Burns, M., \& Griffin P. (Eds.). (1998). Preventing reading difficulties in young children. Washington, DC: National Academy Press.

Soman, A. (2014). The effect of joining preschools on developing reading and writing skills for the basic stage female students at Um Habiba school in Jordan, $A n$ Najah University Journal for Research - Humanities, 28(4), 791-834.

Torgesen, J. K. (1998). Instructional interventions for children with reading disabilities. In B. K. Shapiro, P. J. Accardo, and A. J. Capute (Eds). Specific reading disability: A view of the spectrum. Timonium, MD: York Press.

Ukrainetz, T. A., Cooney, M. H., Dyer, S. K., Kysar, A. J., \& Harris, T. J. (2000). An investigation into teaching phonemic awareness through shared reading and writing. Early Childhood Research Quarterly, 15(3), 331-355.

USAID. (2012). All children learning, early grade learning brief: JORDAN. From: https://usaidjordankmportal.com/syste $\mathrm{m} /$ resources/attachments/000/000/524/
orignal/Early_Grade_Learning_Brief_Jo rdan_2012_.pdf?1456742106.

Vygotsky, L.S. (1978). Mind in society. Cambridge, MA: Harvard University Press.

Wagner, R., \& Torgesen, J. (1987). The nature of phonological processing and its causal role in the acquisition of reading skills. Psychological Bulletin, 101, 192-212.

Walmsley, S., \& Walmsley, B. (1996). Kindergarten: Ready or not?. Portsmouth, NH: Heinemann.

Westwood, P. (2004). Learning to read. In Reading and learning difficulties: Approaches to teaching and assessment. London: David Fulton.

Yeh, S. (2003). An evaluation of two approaches for teaching phonemic awareness to children in Head Start. Early Childhood Research Quarterly, 18(4), 513-529. doi:10.1016/j.ecresq.2003.09.009

Yopp, H. K., \& Yopp, R. H. (2000). Supporting phonemic awareness development in the classroom. The Reading Teacher, 54, 130143. 